
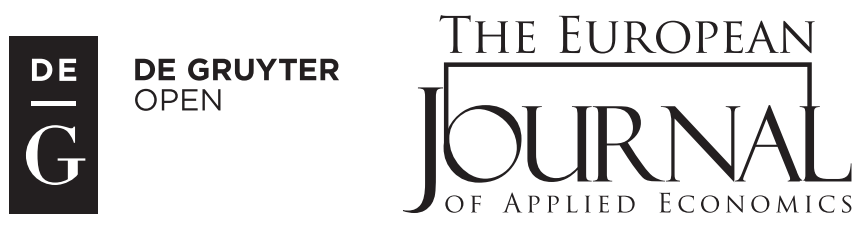

EJAE 2016, 13(1): 24-35

ISSN 2406-2588

UDK: $658.14 / .17(497.11)$

338.246.025.88(497.11)

DOI: $10.5937 /$ ejae13-9688

Original paper/Originalni naučni rad

\title{
FINANCIAL ANALYSIS OF SERBIAN COMPANIES UNDERGOING PRIVATIZATION
}

\author{
Nino Vesković* \\ Singidunum University \\ 32 Danijelova St., Belgrade, Serbia
}

\begin{abstract}
:
This study presents a financial analysis of companies undergoing the process of privatization in the Republic of Serbia (RS). A total of 182 of such companies were examined and compared to an equal number of randomly chosen companies of comparable size. The results revealed a significant gap between the financial performances of the two samples. For that reason, the companies undergoing privatization need to undergo radical changes for the purpose of achieving a higher level of profitability and preventing further losses. Given that these companies pose a significant challenge for the Serbian economy, the author believes that this study will serve as a reference for further research. In addition, this manuscript shall present the comparative analysis of the total net loss of the observed companies and the gross domestic product of the RS, as well as between the corresponding number of employees for the year 2013.
\end{abstract}

\section{Key words:}

privatization, profitability, debt, liquidity, Z-score model, financial statement analysis.

\section{INTRODUCTION}

Pursuant to the Law on Social Capital (The Official Gazette of the Socialist Federal Republic of Yugoslavia, 1989), the privatization process was launched in Serbia in 1989 as the first step in the attempt to transform the state-owned companies into private entities. Table 1 provides a list of relevant legislation and rules related to the privatization process in the Republic of Serbia (RS) for the period from 1989 to 2001.

According to the Privatization Agency of the Republic of Serbia (2005), the Serbian Parliament adopted the so-called Revaluation Law by mid-
1994, which placed an obligation upon all (partially) privatized firms to revalue their outstanding payments for shares previously purchased by employees. The purpose of that was partly to annul the windfall gains acquired by buying shares during the peak of hyperinflation that took place in 1992, and especially in the latter half of 1993. Privatization came to a standstill in the following two years, whereas 436 previously privatized companies restored their socially-owned status in 1995 and 1996. Many cases were subject to long court procedures, which failed to result in a swift verdict.

October 2000 was undoubtedly a milestone, both in regard to politics and the renewal of society, and as such it brought about a new privatiza- 
Law on Social Capital (The Official Gazette of the Socialist Federal Republic of Yugoslavia, 1989)

1990

Law on Conditions and Procedure of Transformation of Social Property into Other Forms of Ownership (The Official Gazette of the Republic of Serbia, 1990)

1994

Law on Amendments and Supplements to the Law on Conditions and Procedure of Transforming Social Property into Other Forms of Ownership

1996

Law on the Basis of Change of Ownership of Social Capital FRY

Law on Ownership Transformation (The Official Gazette of the Republic of Serbia, 1997)

Table 1. Relevant laws on privatization in the RS 1989-2001

tion methodology in the RS. The central institution responsible for implementation of the privatization process in Serbia has been the Privatization Agency (PA), founded in 2001 in line with the Law on Privatization (The Official Gazette of the Republic of Serbia, 2001). The privatization process is structured through the following key tasks performed by the Privatization Agency: 1) promotion; 2) implementation; 3) control and 4) capital representation.

However, due to an overwhelming number of state-owned companies, privatization still poses a pressing issue in Serbia. The case study on privatization in Serbia, carried out by the National Alliance for Local Economic Development (2014), implies that during the period from 2002 until 2013, local governments received 90.3 million euros, i.e. an average of 7.5 million per year. However, when calculating the number of local councils, it becomes apparent that such an amount is symbolic per local council. Apart from this, the aforementioned distribution of income was quite uneven, given that the number of privatizations, the size of the companies and revenues per local governments differed drastically.
According to the Privatization Agency of the Republic of Serbia (2015), 537 state-owned companies undergoing the privatization process, whose debt in 2010 exceeded 4.9 billion euros, have been incurring constant losses, but still had the largest assets in the amount of 4.7 billion euros. Moreover, the total net loss (TNL) of sampled companies undergoing privatisation in 2013 was about 650,038 million euros. At the same time, the gross domestic product (GDP) of the RS for the same year was 34,263 billion euros. The ratio between these values suggests that TNL poses $2 \%$ of GDP. Even though this percentage might appear as low, it is not conclusive given that it comprises only 182 companies out of more than 500 companies subject to the privatization process in the RS. Furthermore, the number of employees in these companies is also well worth observing. Our sample encompasses 89,187 employees in 182 companies undergoing privatization in 2013 , which is $5.20 \%$ of the total $(1,715,164)$ of all employed persons in the RS during that year, according to the Statistical Office of the Republic of Serbia, (2015). Although the labour force tends to claim that there has been an overwhelming potential for further development, it apparently has not existed for decades. 
The main impediments are the absence of: 1) adequate strategy; 2) developed product; 3 ) market competitiveness and 4) rational spending of funds. Nevertheless, the author assumes that political influence is present as well, due to the increasing unemployment rates in the country, which is a direct consequence of these companies being shut down. Therefore, we have conducted this research in order to show how, at this stage, the companies undergoing privatization pose a considerable issue for the Serbian economy.

In order to determine this, the principal aim of this paper - and hence its key potential contribution - is to analyse companies undergoing privatization, by measuring their business performances from the financial point of view. Moreover, the study intends to present how attractive they are for those rational, potential investors, who shall most certainly pay attention to similar things. We aim to accomplish this by performing a financial statement analysis of 182 companies presented by PA, as well as 182 other companies in the RS (which have not been made part of the privatization process), which will be used as a market benchmark. The following section shall discuss the literature background of this study, together with the research methodology and calculations. Upon presenting the research results, the author shall conclude with a short discussion and provide recommendations for future research.

\section{LITERATURE REVIEW}

The literature abounds in studies based on the positive and negative effects of privatization. Mueller (1989), and Vining \& Boardman (1992) have performed numerous surveys while preparing the studies on public and private enterprises around the world. Most of them reveal that public enterprises are less efficient than those in the private sector. Furthermore, Megginson, Nash, \& Van Randenborgh (1994) compared the pre- and post-privatization periods within the financial and operating performance of 61 companies from 18 countries and 32 industries that had undergone either full or partial privatization through public share offerings during the period from 1961 to 1990. The results reveal significant improvements in performance, achieved, though surprisingly, without having to sacrifice employment security. According to the World Bank study carried out by Kikeri, Nellis, \& Shirley (1994), thousands of state companies all over the world have gone private, due to the fact that more than 80 countries have launched ambitious efforts to privatize their state-owned companies. Another good example of privatization benefits was provided by Porta \& Lopez-de-Silanes (1997), who collected data on all 218 non-financial enterprises privatized in Mexico in the period from 1983 until 1991. They found that the privatized companies quickly bridged the pre-privatization performance gap with industrymatched control groups. This was proven by the fact that privatization was accompanied by a 24 percentage point increase in the operating income to sales ratio.

However, according to numerous authors, the problem of state-owned companies is not ownership, but rather the lack of explicit goals and objectives, as well as the absence of organizational culture and systems that would support and encourage it. In that sense, Čerović, Stanišić, Radojević, \& Radović (2015) explored the relationship between the ownership structure and corporate performance, referring to the example of the Republic of Serbia. They were able to prove that both state and socially-owned enterprises were significantly less profitable during the observed periods in comparison to the privately-owned entities. However, they assumed that the problem was actually that they intensified the agency problem and impeded the entrepreneurial spirit. Therefore, negative correlations were expected to exist between them and profitability. Under certain circumstances, privatization could aid the fulfilment of a company's goals and objectives because of the culture and systems it fosters; though in other cases this does not apply (Vernon-Wortzel 
\& Wortzel, 1989). Many studies confirm that a change to private ownership, especially where state regulation remains, may produce fewer economic benefits (Bishop \& Thompson, 1992; Boussofiane, Dyson, \& Thanassoulis, 1991; Burns \& WeymannJones, 1994; Parker \& Martin, 1995; Price \& Weyman-Jones, 1996; Vickers \& Yarrow, 1988).

Both positive and negative effects of privatization and ownership in transition economies were presented in the Journal of Economic Literature by Estrin, Hanousek, Kocenda, \& Svejnar (2009), which might be relevant for further discussion in this paper.

Although almost all of the previously mentioned countries have successfully finalized the process of privatization, this is not the case in the RS. The authors in RS have mostly written about the privatization process in general (Đuričin, Zec, \& Mijatović, 1995; Dugaljić, 2013; Hadžić, 2002; Nikolić \& Kovačević, 2014; Vujačić \& PetrovićVujačić, 2011), whereas some of them have written particularly about the corporate restructuring process of state-owned companies (Dondur, Rodojević, \& Veljković, 2007; Stošić, 2014). The analysis of state-owned companies carried out by Ranković \& Ilić (2001) has indicated the actual issues of that period. They concluded that there would have been little hope for genuine recovery in case responsible authorities had not been aware of those issues. Ostojić (2002) advocated that state-owned companies had a clear role in every economy. According to him, Serbian state-owned companies required very careful reorganization of the public sector rather than urgent privatization. Eleven years later, Dugaljić (2013), wrote: "Nobody questions the necessity of a sound and comprehensive reform of the public sector enterprises, but what has to be taken into account is their objectively large significance for the entire Serbian economy". Dedeić (2013) attempted to point out to the possible solution through comparing the results and effects of the opposing concepts of privatization and nationalization. Such solution would lead to economic growth and overcoming the crisis. Despite the above-stated, the authors in the RS have not paid sufficient attention to measuring business performances of state-owned companies undergoing the process of privatization. So why do the potential investors show so little interest in them? We shall therefore attempt to find answers to these questions by performing a financial statement analysis, focusing on indicators of measuring profitability, liquidity, debt, etc., such as current ratio, return on assets, and Altman's Z score model. We believe that by presenting the real image of companies undergoing privatization, from a financial perspective, other researchers might be encouraged to go further with the analysis.

\section{METHODOLOGY}

For the purpose of the analysis, we have collected financial statements for 182 out of more than 500 companies undergoing privatization. Financial reports of the sample entities have been collected from the official online data service maintained by the Serbian Business Registers Agency, whose basic function is the registration of business entities and tracking of their activity. Financial statements for the accounting periods 2010, 2011, 2012 and 2013 have been acquired and analysed for each and every company. Although there are about 500 companies presented by the Privatization Agency, we were limited due to the publicly accessible financial statements needed for the analysis.

On the other hand, in order to accomplish previously defined research goals and make a comparison, we have collected 182 financial statements of the companies that have not been subject to the privatization process. The activities of the companies presented by the Privatization Agency are diverse, encompassing almost all industrial sectors. Therefore, we have applied the random sampling method to the companies in order to make a reliable comparison. The comparable companies encompass mostly medium and large entities in the RS, belonging to various industrial 
sectors. In 2013, both types of the sample companies, namely those undergoing the privatization process and the comparable ones, had the average values of assets in the amount of 34,668 million euros and 18,826 million euros, respectively. Furthermore, comparable companies had the average operating revenue of 11,873 million euros, whereas companies undergoing privatization had 18,826 million euros during the same year. However, it should be noted that the random sampling technique is the most relevant one, primarily due to a wide range of sectors encompassed within both samples. Despite the fact that the financial statement analysis was conducted for the four-year period, we shall present only the indicators for the year 2013, as the most relevant for further analysis. The reason for this is that all changes from the previous years are generally reflected in 2013, as the last year of the observation period.

As for the research methodology, we will mostly use calculation methods presented by Knežević, Stanišić, \& Mizdraković (2013). The analysis intends to cover: 1) debt; 2) liquidity; 3) profitability; 4) Altman Z-score model and 5) the sustainable growth rate. The debt ratio will be used to assess the impact of debt on business activity. In order to determine liquidity, the relationship between current assets and current liabilities will be used, better known as The Current ratio. Return on Assets, The Net Margin and The Operating Margin shall be used to explain profitability. For the purpose of bankruptcy prediction and credit risk measurements, the Altman Z-score model (Altman, 1968) shall be used, calculated by the following equation:

\section{$Z^{\prime}=0.717 \mathrm{xT} 1+0.847 \mathrm{xT} 2+3.107 \mathrm{xT} 3+0.420 \mathrm{xT} 4+0.998 \mathrm{xT} 5$}

In order to determine the typical values of indicators, we will use the median values of our samples, and all the indicators will be graphically presented by means of the Kernel Density Plot. Given that only certain companies have extreme values of some indicators, they will be excluded only from the graphical visualisation. Therefore, in order to visualize our sample data, we will perform outlier exclusion procedures with cut points established at specific values. However, these companies will be retained within the analysis for the purpose of determining typical indicator's values.

\section{RESULTS AND DISCUSSION}

The debt ratio is the share of external sources to total assets. As shown in Figure 1, in the majority of comparable companies, between $0 \%$ and up to $20 \%$ of assets is financed from borrowed sources, whereas the companies undergoing privatization tend to reflect much higher values. This is undoubtedly the main reason for the lack of interests of potential investors for companies.

Most of the companies subjected to the privatization process have been credited by the government so as to remain operative. Nonetheless, they have continued to record constant losses, year by year.

Figure 2 shows that the control group companies, which have been used as a benchmark in this analysis, have a much better ability to pay shortterm obligations, which makes them competitive and places them in a better market position. On the other hand, low liquidity stems from the inability of companies undergoing privatization to settle their obligations and debts in a timely manner, thus making themselves even less attractive. Moreover, instead of seeking new business strategies and setting new plans for future development, they have been constantly using new loans as the only possible solution.

Profitability is definitely one of the most important items in the decision-making process of an investor. As Michael Porter said: "If your goal is anything but profitability - if it is to be big, or to grow fast, or to become a technology leader -you will face problems". The greatest difference in business performances of the surveyed entities is reflected by the profitability indicators. Based solely on these values, a rational investor could 


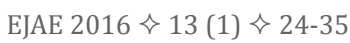

Vesković, N. $\diamond$ Financial analysis of Serbian companies

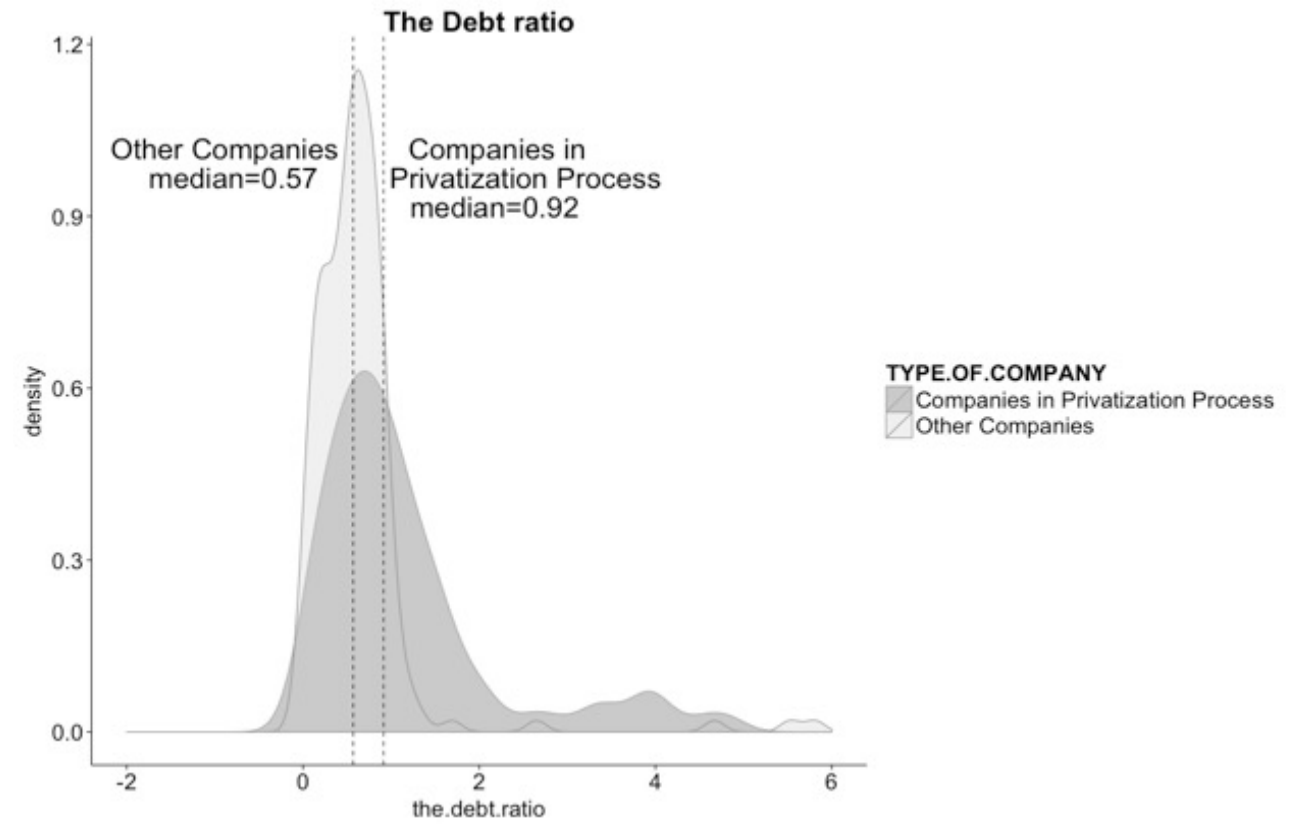

Figure 1. The Debt ratio

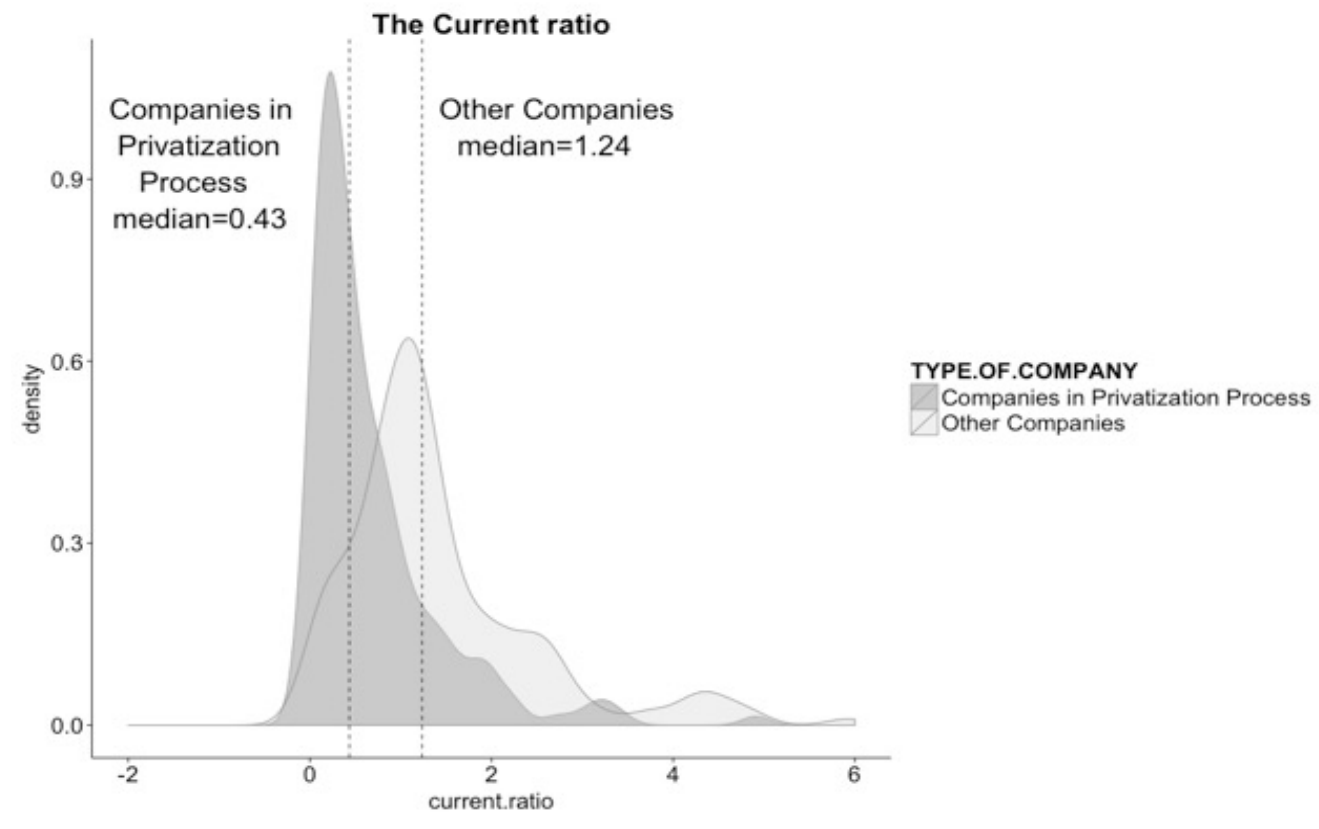

Figure 2. The Current ratio 


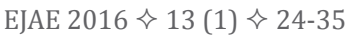

Vesković, N. $\diamond$ Financial analysis of Serbian companies

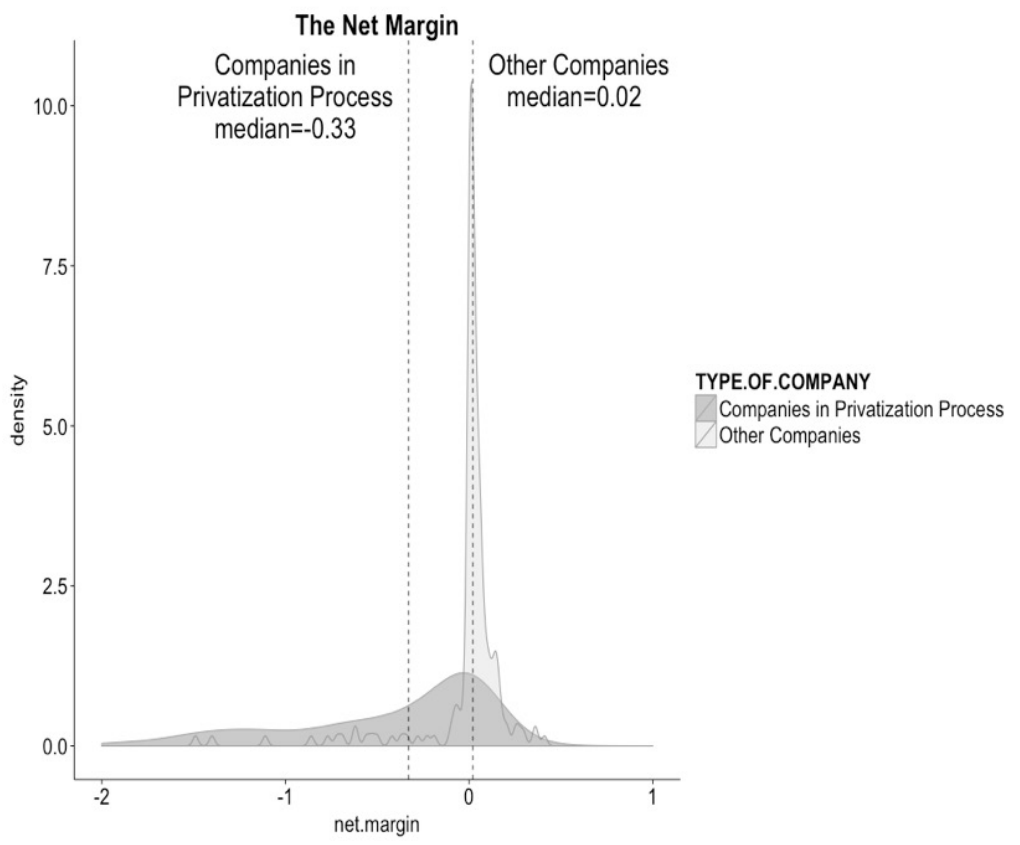

Figure 3. The Net Margin

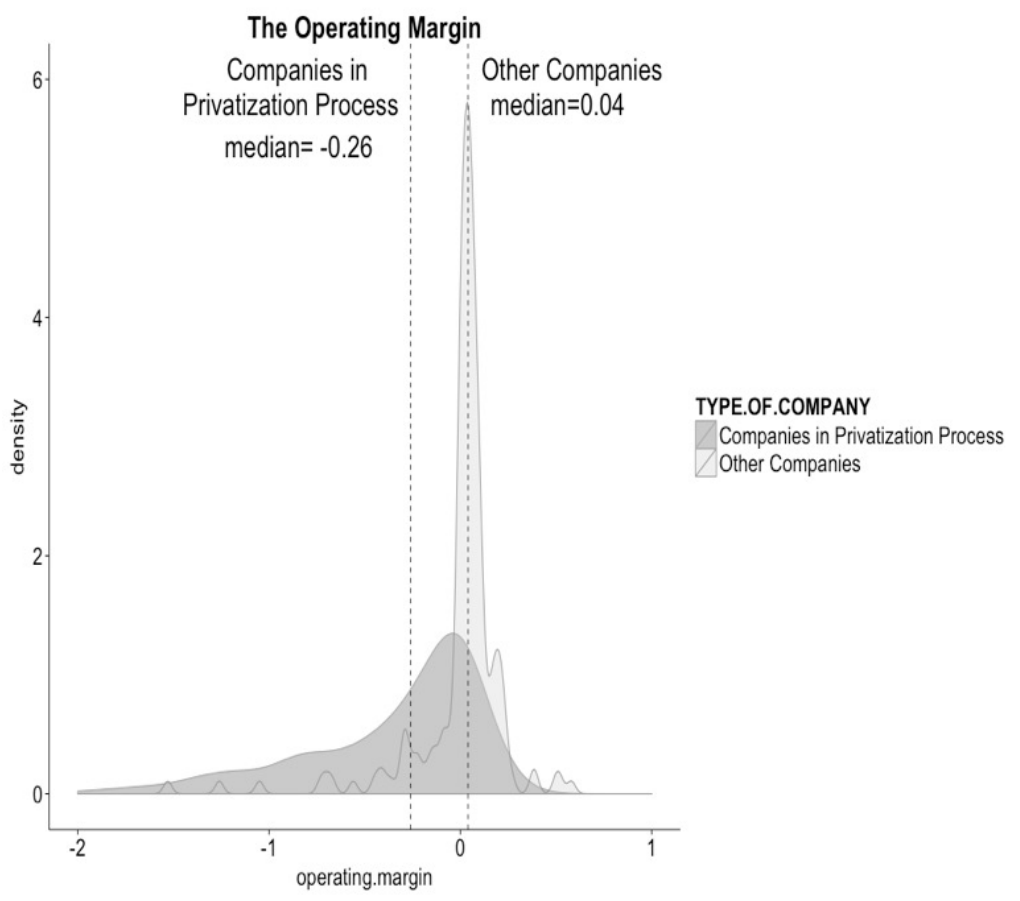

Figure 4. The Operating Margin 


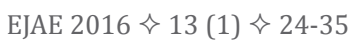

Vesković, N. $\diamond$ Financial analysis of Serbian companies

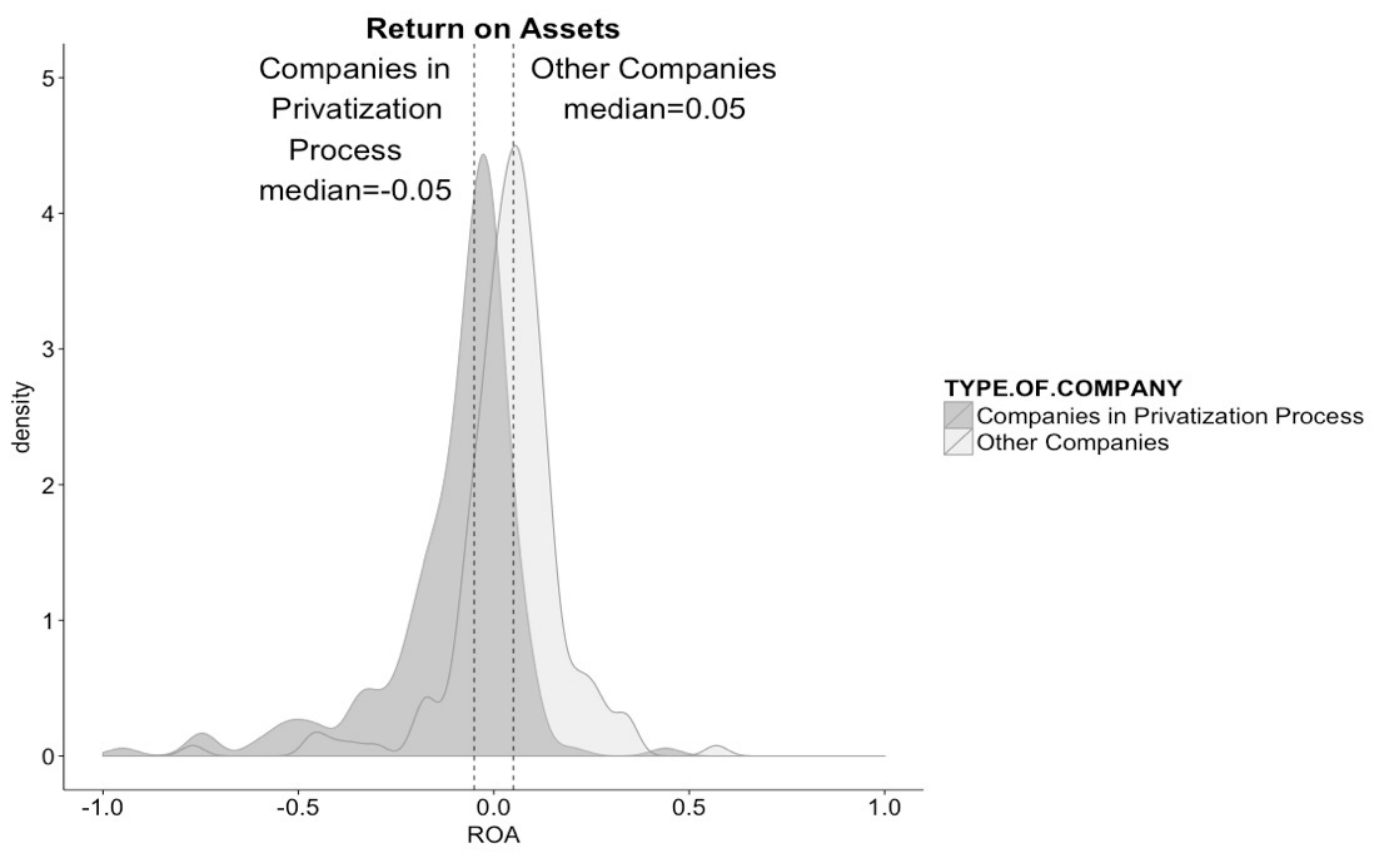

Figure 5. Return on Assets

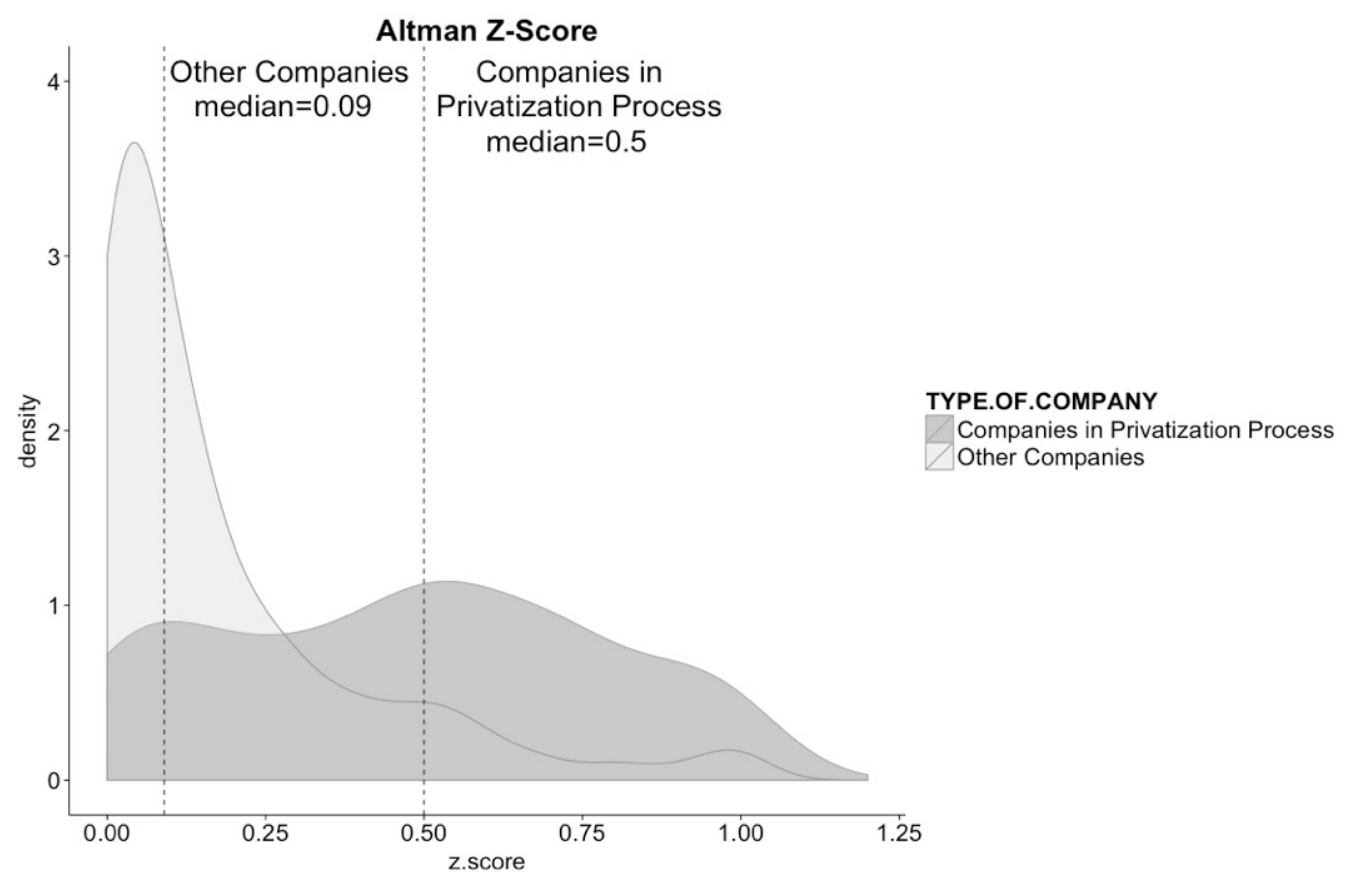

Figure 6. Altman Z-Score 


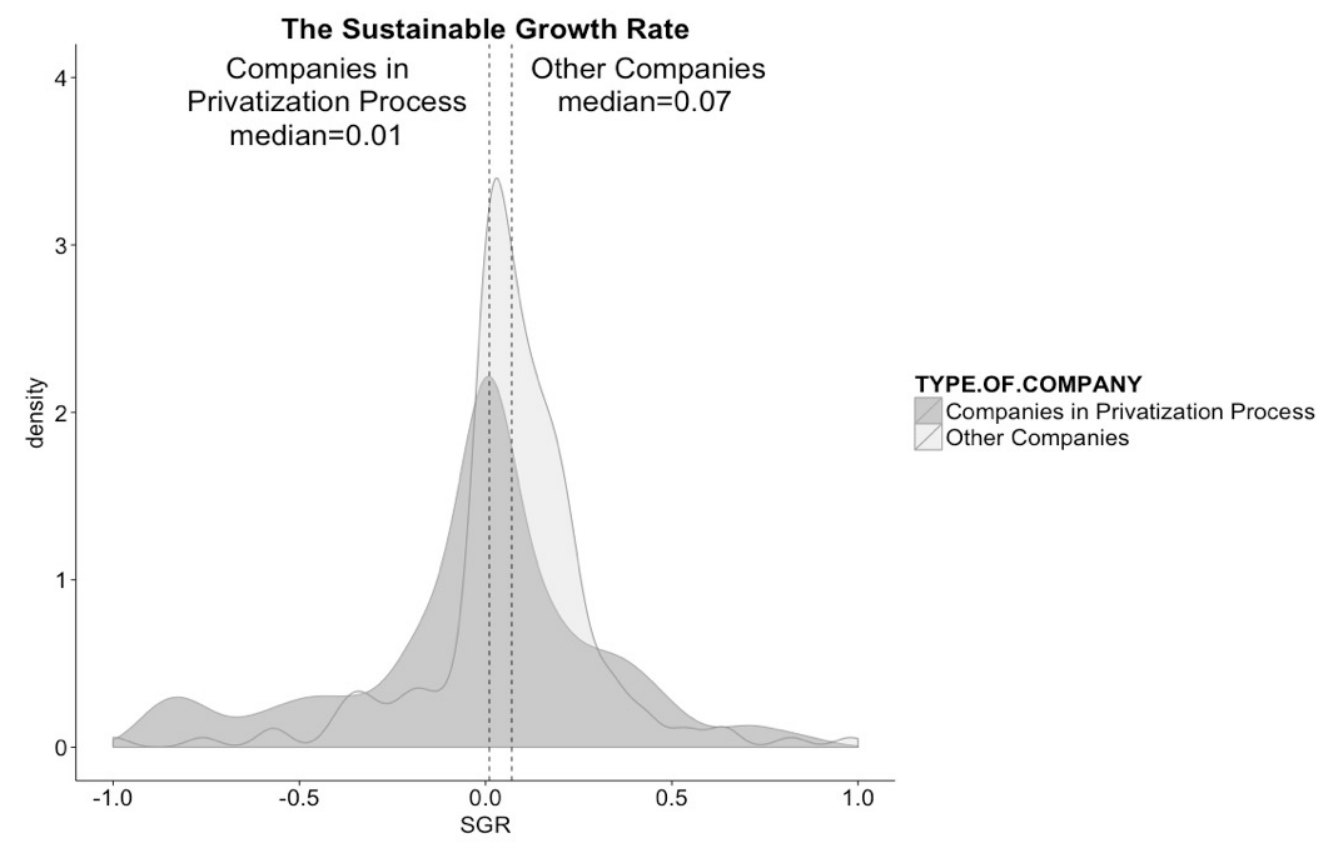

Figure 7. The Sustainable Growth Rate

decide not to invest in a company undergoing privatization, but to choose the company belonging to the control group, if possible. For instance, 126 out of 182 companies undergoing privatization have negative net income, whereas only 39 out of 182 control group companies have negative net income. All of the aforementioned can be seen within The Net Margin histogram, Figure 3. The similar situation could be observed in The Operating Margin histogram (Figure 4), where the comparable companies also display higher values. Nevertheless, companies undergoing privatization appear to manifest a slightly better performance than in the previous indicator due to the operating income, which does not depend on the method of funding and is not under the influence of extraordinary items. The paper shall not present the Return on Equity, given that nearly $50 \%$ of companies undergoing privatization have a negative equity. Return on Assets (ROA) is an indicator of how profitable a company is relative to its total assets. It is basically a reflection of the operating income in this instance, which can be seen in the ROA histogram (Figure 5), where almost $70 \%$ of the companies undergoing privatization are in the negative zone, together with $21 \%$ of comparable companies.

Clearly, the quasi-probability values of corporate bankruptcy, calculated by the Altman ZScore model are relevant for interpretation. The percentage of corporate bankruptcy prediction can be seen in Figure 6. The values display an implicated bankruptcy prediction within a two-year period. Based on the values of our two samples, a large disparity could be observed between them. Figure 6 displays a high bankruptcy probability of companies undergoing the privatization process. Furthermore, the Altman Z-Score model has been indicative of the same issue for many years, which puts a strain on the government in its attempt to keep these companies alive.

The sustainable growth rate is defined as the maximum annual rate at which a firm expects to grow without increasing its financial leverage. However, it seems (Figure 7) that for most companies in privatization, future growth is hardly achievable, unless there is certain improvement in profitability, due to the fact that the financial 


\begin{tabular}{lcccc}
\hline & average & median & average & median \\
\hline The Debt ratio & 1.48 & 0.92 & 0.67 & 0.57 \\
\hline The Current ratio & 0.99 & 0.43 & 3.19 & 1.23 \\
\hline The Net Margin & -160.17 & -0.33 & -1.19 & 0.02 \\
\hline The Operating Margin & -119.88 & -0.26 & -1.04 & 0.04 \\
\hline Return on Assets & -0.11 & -0.05 & 0.02 & 0.05 \\
\hline Altman Z-Score & 0.69 & 0.02 & 3.30 & 2.31 \\
\hline Sustainable Growth Rate & 1.03 & 0.01 & 0.06 & 0.07 \\
\hline
\end{tabular}

Table 2. All indicators previously presented in this paper

leverage has already peaked. Consequently, the only reasonable conclusion might be that the issue is rather a lack of explicit goals and objectives, as well as the absence of organizational culture in these companies.

Table 2 displays median and average values of all indicators used herein. The purpose of it is to summarize all necessary data stemming from this study, which might be useful for further research.

\section{CONCLUSIONS}

We consider the companies undergoing privatisation a significant, but not the only issue affecting the Serbian economy. This research impartially supports this fact from the financial perspective. The comparative analysis of our two samples indicates several reasons as to why there is such low interest in purchasing these companies. Not only does waiting for these companies to be sold incur significant expenses to the citizens of the RS, but it also makes these companies less attractive to potential investors and at the same time reduces their prices. Although we strongly believe that keep- ing these companies in business is not advisable, we can hardly expect for our advice to be directly translated into the best possible solution. It should only serve as a suggestion for further analysis and better understanding of their current situation.

Finally, the authors suggests that closing these companies and selling their assets might be a more effective way towards resolving this rather challenging issue. Moreover, employees should be motivated to launch themselves into entrepreneurial activities using the funds from their severance pays, instead of waiting for a relevant agency to find them a new placement. By encouraging employees to start their own business, the government might be able to solve the problem of the growing unemployment rates that inevitably ensues upon closing of a company undergoing privatization. Nevertheless, in the case of keeping these companies in business, our suggestion is to focus on development of new strategies, competitive products, erosion of the manufacturing base, excess production capacity and redundancy scheme.

A proposal for future research might be setting a time series analysis within the period from 2000 
until 2013, for which the values of net capital of privatization companies will be used. We suppose that the values of net capital have been constantly dropping, year by year. We believe that such hypothesis may strongly support the idea of shutting down these companies as soon as possible and that selling their assets would be the appropriate solution.

\section{Acknowledgements:}

I would like to take this opportunity to express my profound gratitude and deep regards to my professor Nemanja Stanišić, $\mathrm{PhD}$, for his exemplary guidance, valuable feedback and constant encouragement throughout the duration of the research. His valuable suggestions were of immense help. His perceptive criticism kept me working to make this paper the best possible one. Having him as a mentor has been extremely knowledgeable experience for me.

\section{REFERENCES}

Altman, E.I. (1968). Financial Ratios, Discriminant Analysis and The Prediction of Corporate Bankruptcy. The Journal of Finance, 23(4), 589-609. doi:10.1111/j.1540-6261.1968.tb00843.x.

Bishop, M., \& Thompson, D. (1992). Regulatory reform and productivity growth in the UK's public utilities. Applied Economics, 24(11), 1181-1190. doi:10.1080/00036849200000127.

Boussofiane, A., Dyson, R., \& Thanassoulis, E. (1991). Applied data envelopment analysis. European Journal of Operational Research, 52(1), 1-15. doi:10.1016/037722179190331O.

Burns, P., \& Weymann-Jones, T. (1994). Productive Efficiency and the Regulatory Review of Regional Electricity Companies in the UK. Retrieved November 6, 2015, from http://www.opengrey.eu/item/ display/10068/626911.

Čerović, S., Stanišić, N., Radojević, T., \& Radović, N. (2015). The Impact of Ownership Structure on Corporate Performance in Transitional Economies. Amfiteatru Economic, 17(38), 441-454.

Dedeić, D. (2013). Nastavak privatizacije ili podržavljenje preduzeća u Srbiji. Poslovna ekonomija, 7(2), 175-195. In Serbian.
Dondur, N., Rodojević, S., \& Veljković, Z. (2007). Efekti privatizacije i restrukturiranja u industrijskim preduzećima u Srbiji. Industrija, 35(3), 13-25. In Serbian.

Dugaljić, V. (2013). Privatization of Public Enterprises. Bankarstvo, 42(4), 6-11.

Đuričin, D.N., Zec, M.R., \& Mijatović, B. (1995). Privatization in Serbia. Industrija, 22(1-2), 71-96.

Estrin, S., Hanousek, J., Kocenda, E., \& Svejnar, J. (2009). The effects of privatization and ownership in transition economies. Journal of Economic Literature, 7(402), 699-728. doi:10.1257/jel.47.3.699.

Hadžić, M. (2002). Rethinking Privatization in Serbia. Eastern European Economics, 40(6), 6-23. doi:10. 1080/00128775.2002.11041034.

Kikeri, S., Nellis, J., \& Shirley, M. (1994). Privatization: Lessons from market economies. World Bank Research Observer, 9(2), 241-272. doi:10.1093/ wbro/9.2.241.

Knežević, G., Stanišić, N., \& Mizdraković, V. (2013). Analiza finansijskih izveštaja: namenjeno tržištu Republike Srbije. Beograd: Univerzitet Singidunum. In Serbian.

Megginson, W.L., Nash, R.C., \& Van Randenborgh, M. (1994). The Financial and Operating Performance of Newly Privatized Firms: An International Empirical Analysis. Journal of Finance, 49(2), 403-452. doi:10.2307/2329158.

Mueller, D.C. (1989). Public Choice. Cambridge: Cambridge University Press.

National Alliance for Local Economic Development. (2014). Studija slučaja: Privatizacija u Srbiji. Retrieved from http://www.naled-serbia.org/upload/Document/File/2014_11/Studija_slucaja_ Privatizacija_u_Srbiji.pdf. In Serbian.

Nikolić, I., \& Kovačević, M. (2014). Efekti privatizacije - empirijska analiza i rezultati na srpsku industriju. Industrija, 42(1), 63-86. doi:10.5937/ industrija42-4846. In Serbian.

Ostojić, S. (2002). Državna preduzeća - pro et contra. Ekonomika preduzeća, 50(1-2), 20-28. In Serbian.

Parker, D., \& Martin, S. (1995). The impact of UK privatisation on labour and total factor productivity. Scottish Journal of Political Economy, 40(2), 201220. doi:10.1111/j.1467-9485.1995.tb01154.x.

Porta, R. La, \& Lopez-de-Silanes, F. (1997). The Benefits of Privatization: Evidence from Mexico. Retrieved from http://www.nber.org/papers/w6215. 
Price, C., \& Weyman-Jones, T. (1996). Malmquist indices of productivity change in the UK gas industry before and after privatization. Applied Economics, 28(1), 29-39. doi:10.1080/00036849600000004.

Privatization Agency of the Republic of Serbia. (2015). The Analysis of the Privatization Process. Retrieved November 6, 2015, from http://www.priv.rs/.

Privatization Agency the Republic of Serbia. (2005). Impact Assessment of Privatisation in Serbia. Retrieved from http://www.priv.rs/upload/document/ Impact_Assessment_of_Privatisation_Final.pdf.

Ranković, J. M., \& Ilić, G. (2001). Analiza rentabilitetnog i finansijskog položaja javnih preduzeća Srbije. Ekonomika preduzeća, 49(7-12), 207-213. In Serbian.

Statistical Office of the Republic of Serbia. (2015). Number of employed - total, annual average. Retrieved November 6, 2015, from http://webrzs.stat.gov.rs/ WebSite/public/ReportView.aspx.

Stošić, I. (2014). Korporativno restrukturiranje preduzeća u svetu i Srbiji. Poslovna Ekonomija, 8(1), 157-176. doi:10.5937/PosEko1401157S. In Serbian.

The Official Gazette of the Republic of Serbia.(1990). Law on Conditions and Procedure of Transformation
Social Property into Other Forms of Ownership, No. 48/91, 75/91, 48/94 and 51/94.

The Official Gazette of the Republic of Serbia.(1997). Law on Ownership Transformation, No. 32/97 and $10 / 01$.

The Official Gazette of the Republic of Serbia. (2001). Law on Privatization, No. 38/2001, 18/2003 i 45/2005.

The Official Gazette of the Socialist Federal Republic of Yugoslavia.(1989). Low on Social Capital, No. 84/89 and 46/90.

Vernon-Wortzel, H., \& Wortzel, L.H. (1989). Privatization: Not the only answer. World Development, 17(5), 633-641. doi:10.1016/0305-750X(89)90064-8.

Vickers, J., \& Yarrow, G.K. (1988). Privatization: An economic analysis. Cambridge, Mass: MIT Press.

Vining, A.R., \& Boardman, A.E. (1992). Ownership versus competition: Efficiency in public enterprise. Public Choice, 73(2), 205-239. doi:10.1007/ BF00145092.

Vujačić, I., \& Petrović-Vujačić, J. (2011). Privatization in Serbia: Results and institutional failures. Economic Annals, 56(191), 89-105. doi:10.2298/ EKA1191089V.

\section{FINANSIJSKA ANALIZA SRPSKIH PREDUZEĆA U PROCESU PRIVATIZACIJE}

\section{Rezime:}

Ova studija prikazuje finansijsku analizu privrednih društava na teritoriji Republike Srbije u procesu privatizacije. Istraživanje je obuhvatilo ukupno 182 takvih privrednih društava koja su posmatrana u odnosu na isti broj nasumice izabranih privrednih društava približne veličine. Rezultati upućuju na značajan raskorak između njihovih finansijskih performansi. Stoga je neophodno podvrgnuti privredna društva u procesu privatizacije radikalnim promenama kako bi se ostvario visok nivo profitabilnosti i zaustavili dalji gubici. S obzirom da ova društva predstavljaju značajan izazov za srpsku ekonomiju, verujemo da će ova studija poslužiti kao polazna tačka za dalja istraživanja. Takođe, u radu je prikazano i poređenje ukupnog neto gubitka ispitanih društava u odnosu na bruto domaći proizvod Republike Srbije, kao i odgovarajućeg broja zaposlenih za 2013. godinu.

\author{
Ključne reči: \\ privatizacija, \\ profitabilnost, \\ zaduženost, \\ likvidnost, \\ Z-skor model, \\ analiza finansijskih izveštaja.
}

